\title{
Fluctuations of Pore-water Pressure in a Landslide of Heavy Snow Districts
}

\author{
Sumio MatsuURA*
}

\begin{abstract}
Pore-water pressure fluctuations were observed in a Tertiary landslide, which is located in a heavy snow district, using an automated data acquisition system. Meltwater and/or rainfall $\left(M R_{(a / o)}\right)$, snow-related factors including water equivalent of snow, and landslide movement were simultaneously obtained. The results of observation for two consecutive years showed the long-term effects of snow load on pore-water pressure, such as a gradual rise of pore-water pressure as snow accumulated. An investigation on the time-lag and response ratio of pore-water pressure against $M R_{(a / o)}$ for pre-snow, snow, and post-snow cover periods revealed that the time-lag of pore-water pressure against $M R_{(a / 0)}$ was not uniform before snow started to accumulate, but showed a distribution curve with a clear peak during late snow cover periods. The response ratio of porewater pressure against the $M R_{(a / o)}$ value integrated for one event was investigated, with followings results. The relationship between pore-water pressure and $M R_{(a / o)}$ was diverse in pre-snow cover periods but showed a high correlation in snow cover periods. The response ratio of pore-water pressure against $M R_{(a / o)}$ was high before the snow cover period, gradually decreased as snow accumulated, and was only one tenth of the value in the pre-snow cover period in late snow cover periods. The response ratio remained low even after snow had disappeared and required 500 to 600 hours to return to the level of the pre-snow cover period. Observations of pore-water pressure inside the landslide mass revealed that changes in pore-water pressure during snow cover periods are quite different from those in other periods. These results suggest that the hydrologic coefficients of landslide mass are strongly affected by snow cover.
\end{abstract}

Keywords : pore-water pressure, meltwater, snow load, heavy snow districts

\section{Introduction}

When we analyze the mechanisms of landslide generation, it is very important to clarify the fluctuations of pore-water pressure as there is a close correlation. Pore-water pressure is usually observed by measuring the groundwater level in Casagrande wells or by installing piezometers in the landslide mass. Since a preliminary survey of ground water by bore holes and accurate installation of piezometers are required to observe the pore-water pressure at deep slip surfaces, continuous observation data are more scarce than those for confined or free groundwater that may cause surface failure.

Water levels have only been periodically measured manually by using wells in the early days (Nakamura et al. 1970. Ikeda et al. 1975, Kenney et al. 1984). How-

* Forestry and Forest Products Research Institute (FFPRI) ever, the development of measuring instruments has led to automatic observation of pore-water pressure. Some of the characteristics of pore-water fluctuations caused by rainfall at landslides of Tertiary deposits and Mesozoic or Paleozoic strata are clarified by the data obtained automatically (Higaki et al. 1991, Kondoh et al. 1992, Maruyama 1994, Angeli et al. 1996).

In snow districts, winter-time observation by hand has also been difficult due to severe natural conditions. Recent applications of automated data acquisition systems have gradually revealed the behavior of porewater pressure during winter season at landslides of Tertiary deposit (Ogawa et al. 1987, Maruyama 1993, Matsuura et al. 1998), morainic bar on a bedrock of Werfen marls (Angeli 1988), and quick clay sediment (Okamoto 1999, Larsen 1999).

However, many unclear points, such as the process by which meltwater infiltrates the landslide mass and snow load effects on pore-water pressure, remain. 
Therefore, a landslide in a heavy snow district was selected as a research site where landslide movement, pore-water pressure, snow condition, and other meteorological factors were continuously and automatically observed. Two-year observations showed that porewater pressure is closely related with snow conditions, such as meltwater and water equivalent of snow.

\section{Description of the research site}

The Busuno research site is located on hills of Tertiary deposit, which is widely distributed over the area along the Sea of Japan (Figure 1). This area is strongly dominated by the northeast-southwest geological structure formed after the Neogene. Rocks are fragile due not to deformation from folding but to the semiconsolidated characteristics of the rock itself, resulting in frequent landslides. The dominant rock in this area is mainly black mudstone that corresponds to the Shiiya and Teradomari formations of the Miocene with a little sandstone.

This district belongs to a heavy snowfall zone facing the Sea of Japan. The annual precipitation is about $2,900 \mathrm{~mm}$, which is approximately 1.8 times larger than the mean precipitation in Japan. The precipitation in winter (late November to early May) amounts to 1,300 to $1,600 \mathrm{~mm}$, most of which is snowfall, forming 3 to 5 $\mathrm{m}$ of snow accumulation.

The research site is a 50 to $70 \mathrm{~m}$ wide and about 300 $\mathrm{m}$ long landslide at an altitude of 550 to $630 \mathrm{~m}$ (Figure 2). This landslide is a typical secondary landslide which was formed by the colluvial deposit of the first landslide from the left-bank-side slope. The landslide mass consists of mainly weathered mudstone, the inner structure of which is highly disturbed due to the active landslide motions. The middle block of landslide is underlain by an extremely poor layer of tuff at the depths of 5 to $7 \mathrm{~m}$ forming a slip surface.

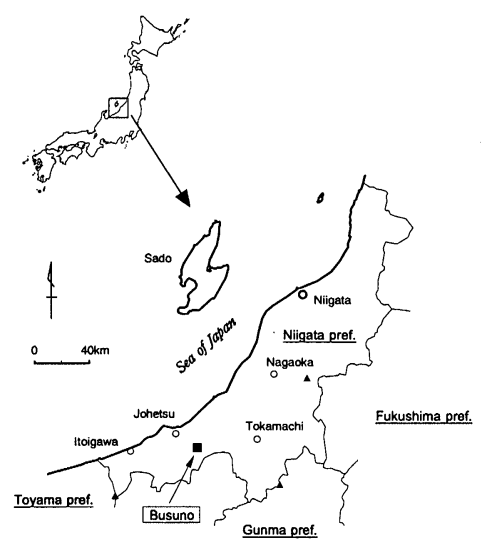

Fig. 1 Location of Busuno research site.
The research site may be classified into four blocks of the upper, middle, lower, and terminal. The upper block forms a main scarp near the ridge. The lower block showed the greatest movement of approximately $5 \mathrm{~m}$ from 1988 to 1989 . The second most active was the middle block, which showed the characteristics of retrogressive landslide, i.e. movement propagating toward the upper sections. At the time of observation, there was no notable movement in the upper block.

\section{Installation of sensors}

\subsection{Rainfall gauge and lysimeters}

To observe the snow conditions in the research site, various sensors were installed at a meteorological station on stable ground near the landslide.

The amount of precipitation was observed throughout a year by using a rainfall gauge equipped with a heater and a windbreak to enhance the acquisition ratio. Since snow was estimated to accumulate up to 3 to $5 \mathrm{~m}$ in winter, the rainfall gauge was set on a concrete pole of $8 \mathrm{~m}$ in height.

In order to observe the timing and intensity of water that flows out from the bottom of snow cover, stainless-steel lysimeters were installed. The data col-

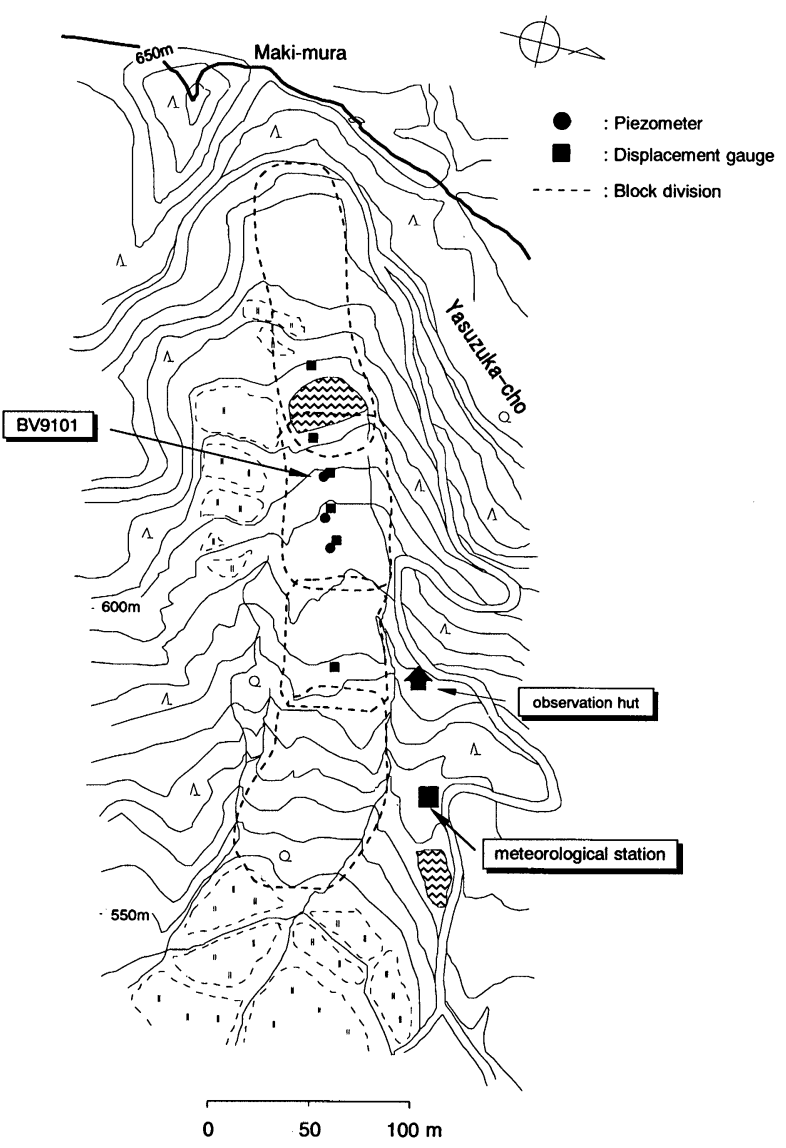

Fig. 2 Overview of Busuno research site and location of installed sensors. 
lected by the lysimeters indicates precipitation for periods with no snow and, for snow cover periods, meltwater (the amount of meltwater which is generated at the top of snow cover including the meltwater at the bottom of snow cover) and/or rainfall on the snow cover (hereafter, denoted as $M R_{(a / o)}$ ).

The lysimeters were $1,000 \mathrm{~mm} \times 1,000 \mathrm{~mm} \times 200$ $\mathrm{mm}$ in size, and were filled with No.4 silicious sand. Four lysimeters were installed so that each of the acquisition sections protruded about $30 \mathrm{~mm}$ from the ground surface, and were connected with pipes to a $500 \mathrm{cc}$ flowmeter installed within a handhole, with which $M R_{(a / o)}$ was measured (Figure 3). The lysimeters collected water from an area of $4 \mathrm{~m}^{2}$, and one turnover of the bucket corresponded to $0.125 \mathrm{~mm}$.

Snow depth was determined by using an ultrasonic snow depth gauge of $\pm 1 \mathrm{~cm}$ precision. The water equivalent of snow was observed every 30 minutes by using a stainless-steel wafer filled with antifreeze solution.

\subsection{Piezometers}

In August 1992, three piezometers were installed in bore holes in the middle block of the landslide (Figure $2)$ : 1) near the slip surface $(\mathrm{M}:-4.30 \mathrm{~m}), 2$ ) beneath the slip surface (D: $-6.00 \mathrm{~m}$ ), and 3 ) in the moving mass above the slip surface ( $\mathrm{U}:-3.25 \mathrm{~m}$ ) (Figure 4). Observation of pore-water pressure started on September 9, 1992. Measurements conducted in the previous year by using a multi-layer displacement gauge had shown that the slip surface was 4.5 to $5.0 \mathrm{~m}$ deep.

The piezometers used were semi-conductive type pressure gauges of $100 \mathrm{kPa}$ full scale. Due to the builtin amplifier type of sensor, it has a wide range of input

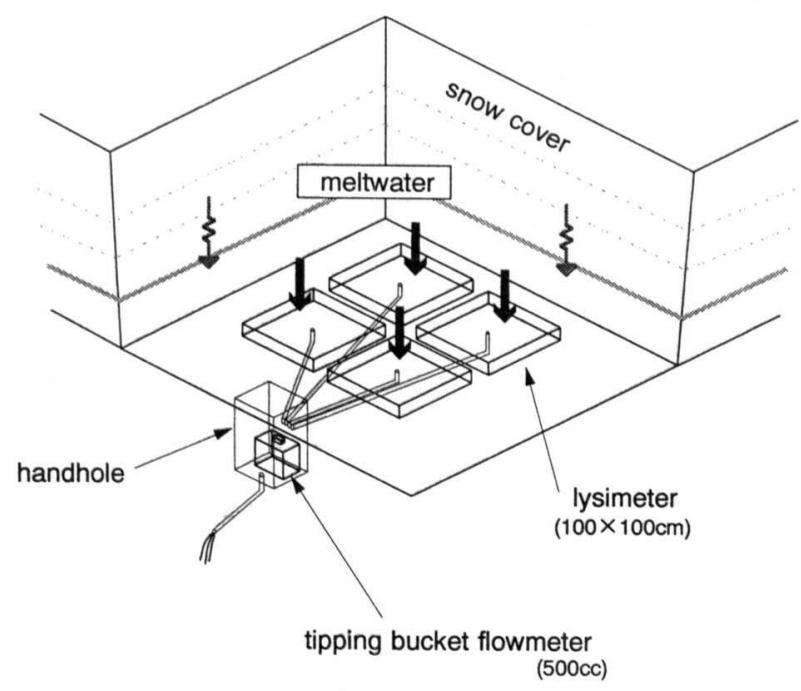

Fig. 3 Schematic diagram of meltwater observation system. voltage of 12 to $15 \mathrm{~V}$ and outputs an electric current signal of 4 to $20 \mathrm{~mA}$, which is not affected by line resistance. Cables reinforced with aramid fibers were used for the piezometers to resist active landslide movement of the research site. The piezometers were installed in a bore hole made by casing drilling at each depth. The space around piezometer was filled with silicious sand for $1 \mathrm{~m}$ and top-and-bottom spaces were plugged with bentonite pellets to stop water so as to measure only specified pore-water pressures.

Observation was conducted every 30 minutes, the same interval as the meteorological data collection. The piezometer under the slip surface (D) ceased observation after three months since a long-distance landslide movement destroyed its sensor. The other two piezometers above the slip surface continued observations for over two years.

\section{Results and discussion}

\subsection{Meteorological data and landslide movement}

The amount of precipitation, lysimeter measurements, snow depth, and pore-water pressure values

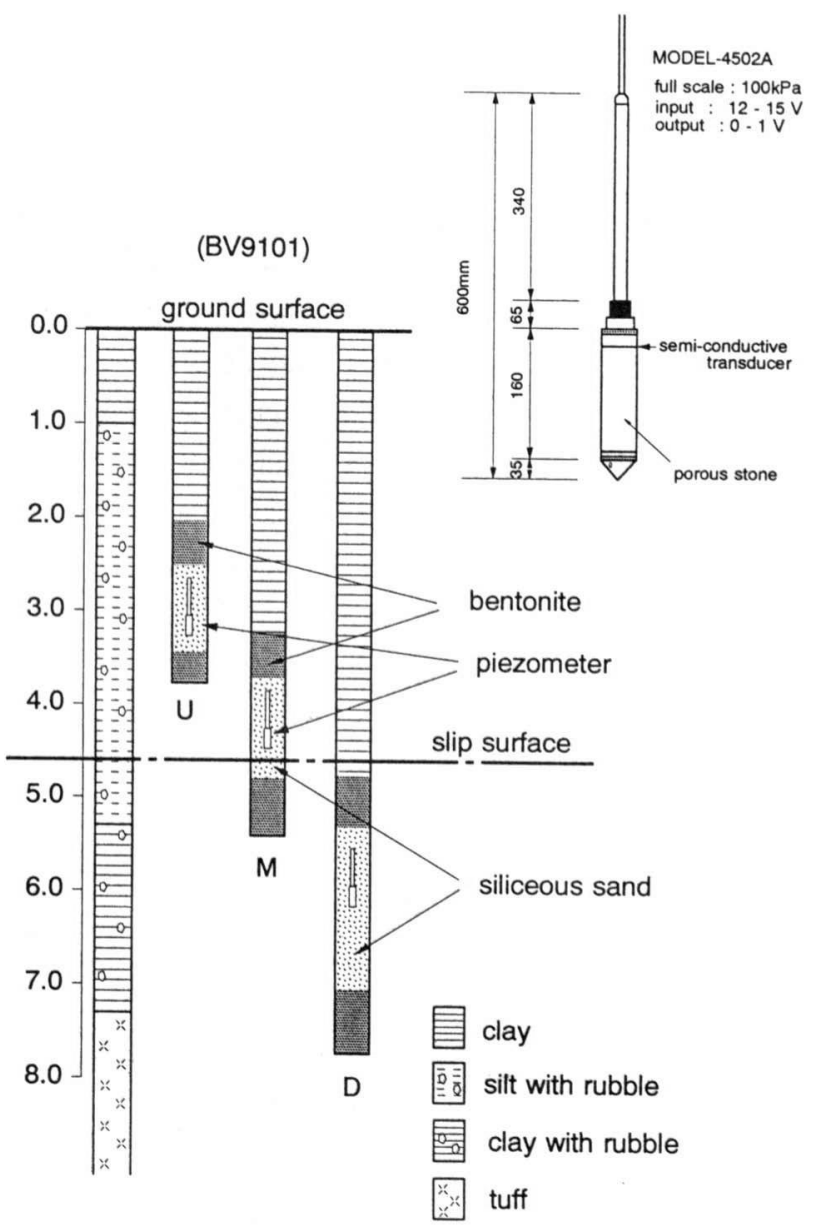

Fig. 4 Basic configuration of piezometer and its installation. 
from September 1992 to August 1994 are shown in Figures 5 and 6 . In this paper, the author define that a winter year begins in September and ends in the next August. The 1993 winter year $\left(1993_{\text {wy }}\right)$ means the period from September 1992 to August 1993.

The annual precipitation was $2,763 \mathrm{~mm}$ for $1993_{\mathrm{wy}}$ and $2,014 \mathrm{~mm}$ for $1994_{\mathrm{wy}}$. The period in which the largest amount of water reached the ground surface was from March to May, when snow melts. Snow cover that is equivalent to $1,300 \mathrm{~mm}$ accumulates during winter. Snow melts with high intensities during the snowmelting period of about 60 days, resulting in runoff from the snow pack. The largest amount of $M R_{(a / o)}$ throughout both winter years was recorded on April 12,1994 , with $176 \mathrm{~mm} /$ day, when foehn brought warm and strong winds. Much $M R_{(a / o)}$ was also recorded during the rainy season (June and July) and during September and December. The deepest snow cover was $315 \mathrm{~cm}$ and $290 \mathrm{~cm}$, respectively. Both winter years showed smaller values than the mean maximum snow cover depth $(350 \mathrm{~cm})$ of the district. The cumulative
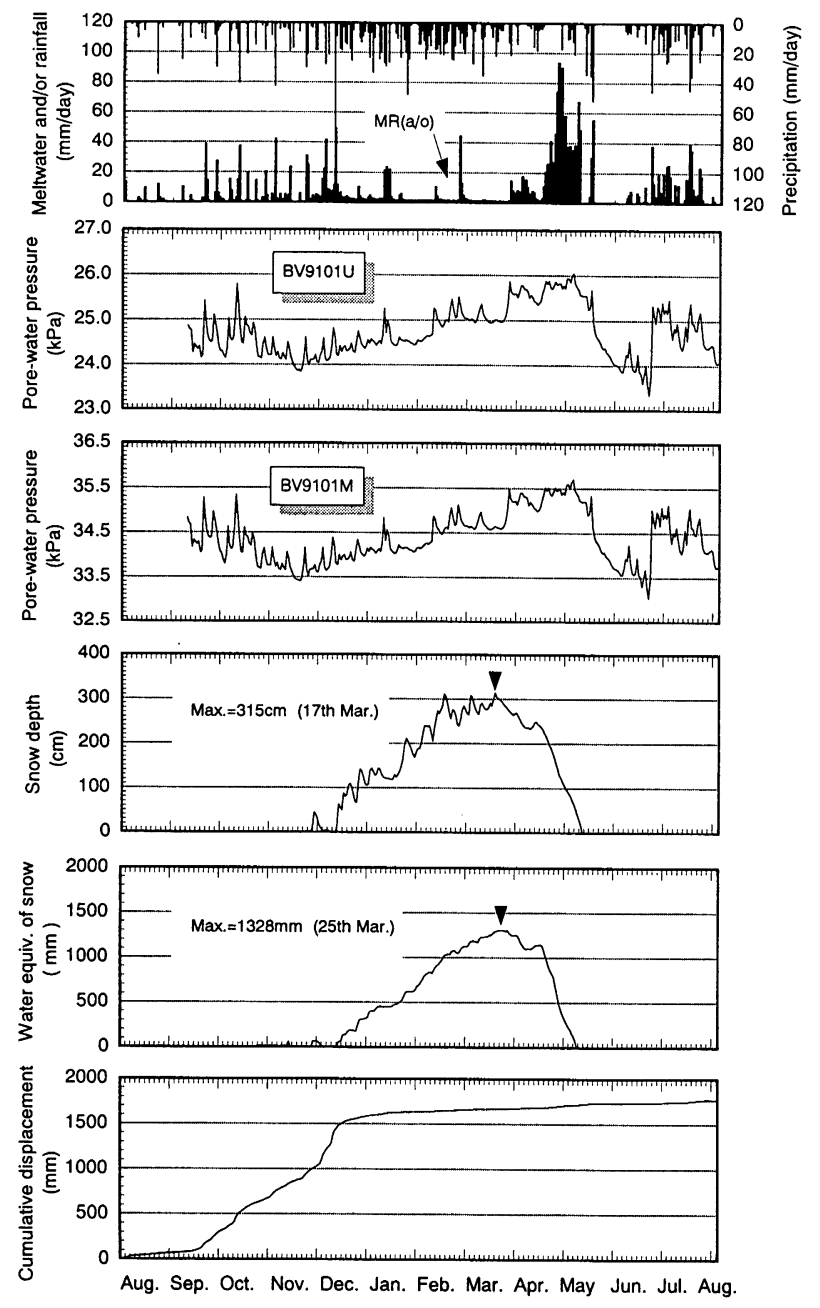

Fig. 5 Results of observation (1992-1993). landslide movement, which was observed simultaneously with pore-water pressures by using a multi-layer extensometer, recorded $1,700 \mathrm{~mm}$ and $1,250 \mathrm{~mm}$, respectively.

\subsection{Long-term fluctuation of pore-water pressure}

Observations of pore-water pressure for two years showed that the pore-water pressure slowly decreased at the beginning of 1993 and 1994 winter years, gradually rose when snow began to accumulate, and reached the largest values in the snowmelting period. The pressure dropped thereafter more rapidly than it had risen. This tendency continued even after all snow had disappeared. Both winter years recorded the lowest pressure values 3 to 4 weeks after snow had disappeared, but the difference between the highest and lowest pressure values was only about $2 \mathrm{kPa}$.

To study quantitatively the long-term trend of porewater pressure for both winter years, pore-water pressure data for the periphery of the slip surface was obtained by an approximate polynomial calculation and Stineman smoothing processing (Figure 7). Both winter
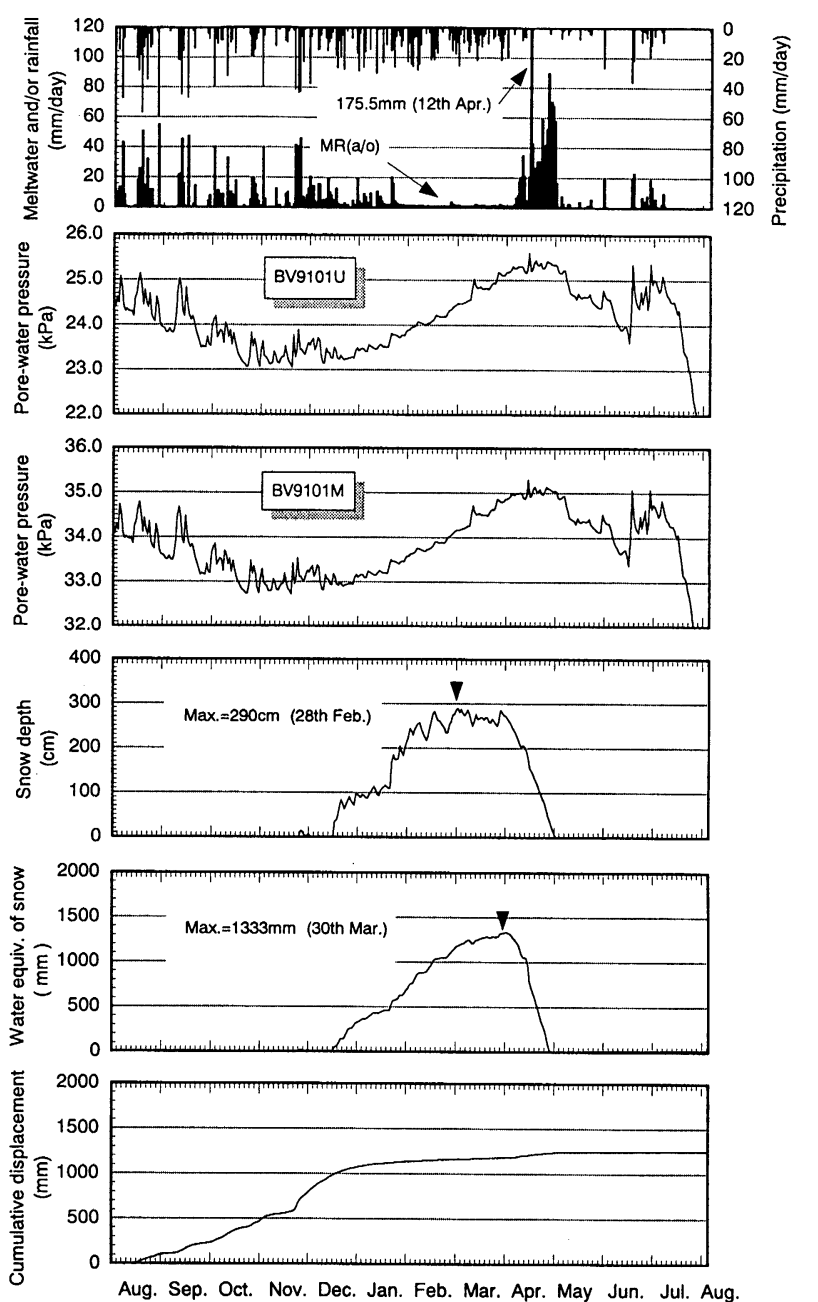

Fig. 6 Results of observation (1993-1994). 
years showed a similar tendency of increasing porewater pressure during snow cover periods. Such longterm fluctuation was also observed at the Sarukuyoji landslide in a Tertiary deposit, and a correlation with snow cover was found (Maruyama, 1993). Maruyama's analysis, however, was only an estimate since not water equivalent of snow but snow depth was observed. Observations at the Busuno research site showed that the fluctuation of pore-water pressure is related with water equivalent of snow more closely than with snow depth. For both winter years, water equivalent of snow of over $1,300 \mathrm{~mm}$ was recorded at the meteorological station. Snow load of 12 to $13 \mathrm{kN} /$ $\mathrm{m}^{2}$ was likely acting on the landslide slope although the values may have differed by place, and likely raised the pore-water pressure within the landslide mass.

For both winter years, the pore-water pressure before snow cover periods showed large fluctuations but an overall decreasing tendency. The relationship between pore-water pressure and traveling distance of landslide is likely the key for this drop. It seems that long landslide movement before the snow cover period loosened the mass, resulting in the decrease of porewater pressure. On the other hand, although porewater pressure was high during snow cover periods, the rate of landslide movement was reduced. The increase in effective stress generated by snow loads is a likely cause of this phenomenon. The observations of long-term fluctuation in pore-water pressure showed a tendency that is opposite of previous findings, i.e., a rise in pore-water pressure increases landslide movement.

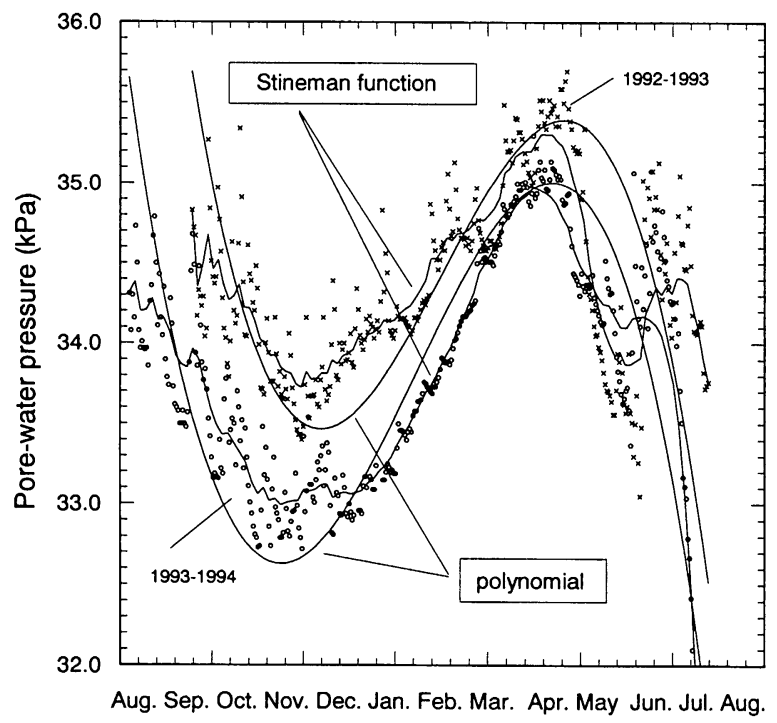

Fig. 7 Long-term trend of pore-water pressure.

\subsection{Response characteristics of pore-water pressure against $M R_{(a / 0)}$ for each winter year}

\subsubsection{Analytical methods}

The response characteristics of pore-water pressure against $M R_{(a / o)}$ should differ between the snow cover period and others even in one winter year (Figure 8). One winter year was divided into three periods, which are 1) from September to the beginning of the snow cover period (pre-snow), 2) snow cover period, and 3) after snow disappeared to August (post-snow), and the fluctuation characteristics of pore-water pressure in terms of $M R_{(a / o)}$ for each period were investigated. The snow cover period was further divided into the early (late November to January) and late (March to early May) snow cover periods. The analysis was conducted by using the pore-water pressure data for the periphery of the slip surface. Ground freezing in winter should not be considered since this region belongs to the temperate zone and is covered by several meters of snow.

Response functions, storage functions, and tank models have been used to predict the fluctuation of pore-
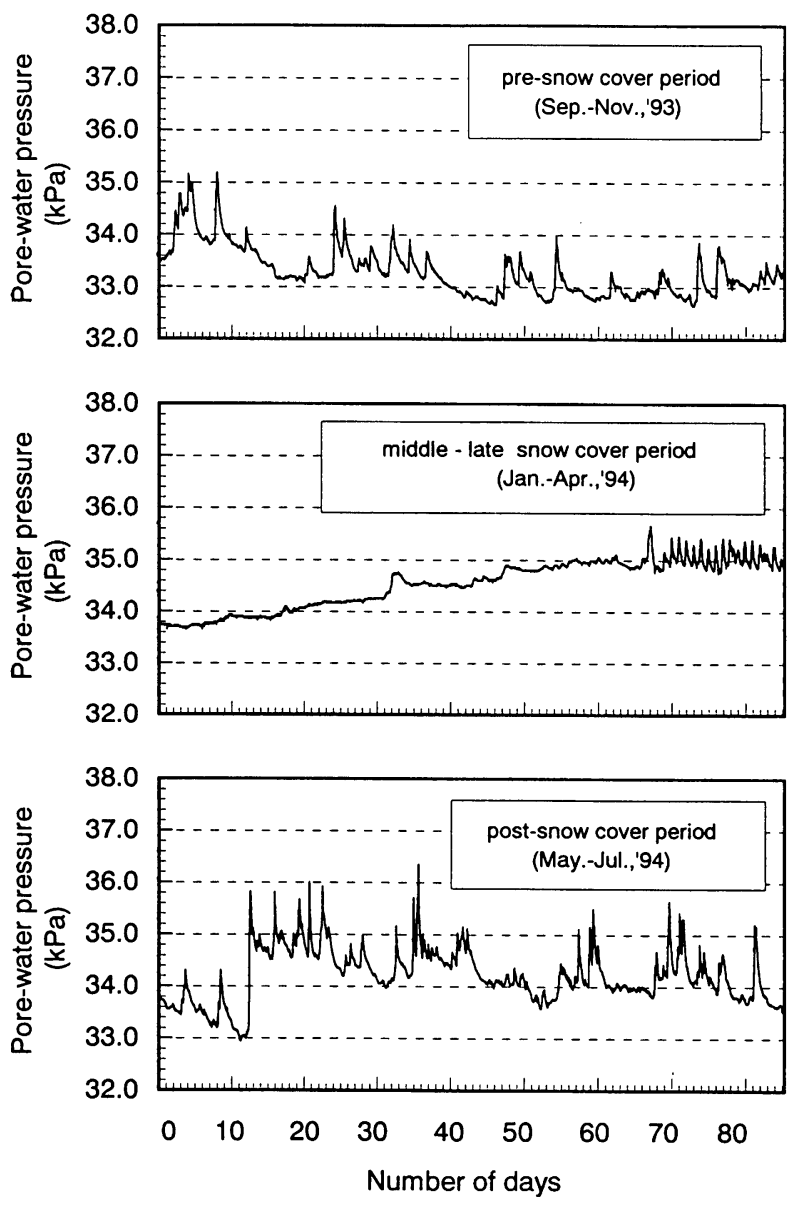

Fig. 8 Fluctuation of pore-water pressure in different periods. 
water pressure (Sangrey et al. 1984). These methods are effective in applying waveforms and have been used to predict future changes based on acquired data but not to understand the fluctuation characteristics of pore-water pressure. The aim of this study is not to predict the fluctuation of pore-water pressure but to study the fluctuation characteristics of pore-water pressure for the snow cover and other periods based on observation data. Therefore the extracted porewater pressure changes caused by $M R_{(a / o)}$ were analyzed using the unit response functions, which are widely used for run-off analysis. Furthermore, to derive the response characteristics of pore-water pressure for each period, statistical analyses of the obtained data were performed.

The changes in pore-water pressure caused by $M R_{(a / o)}$ that was at least $1 \mathrm{~mm}$ in 30 minutes and amounted to at least $3 \mathrm{~mm}$ in total, was selected first. Then, recession curves of response waveforms, which were disturbed by consequent events, were eliminated to obtain accurate response characteristics. In this paper, it is defined that one event starts at the beginning of a continuous $M R_{(a / o)}$ and ends when the waveform of pore-water pressure has converged to the approximate long-term trend curve.

For the two winter years, 84 response waveforms of pore-water pressure were extracted in the selection process. Some data for the $1993_{\mathrm{wy}}$ snow-melting period and the $1994_{\mathrm{wy}}$ pre-snow cover period were missing due to a submerged flowmeter and a defective pulse counter.

After the selection of events, the integrated value of $M R_{(a / o)}$ for each 30 minutes was converted into a waveform with the center line at the 15-minute value. At this point, there was a time-lag of 15 minutes since piezometers recorded the momentary value every 30 minutes. The $M R_{(a / o)}$ data were spline corrected, and consequently data for 10 minutes were generated. These data were used to calculate the peak intensity $\left(H_{M R(a / o)}\right)$, the time that the peak appeared $\left(T_{M R(a / o)}\right)$, and the integrated value $\left(\Delta S_{M R(a / o)}\right)$ for each event. For pore-water pressure, the momentary values for each 30 minutes were also spline corrected, and data for 10 minutes were generated. The peak pore-water pressure intensity corresponding to $M R_{(a / o)}\left(H_{p w p}\right)$, the time that the peak appeared $\left(T_{p w p}\right)$, the integrated value $\left(\Delta S_{p w p}\right)$, and duration $(L)$ were determined respectively (Figure 9). The characteristics of $M R_{(a / o)}$ and porewater pressure waveforms were investigated separately first, and then compared with the waveforms in terms of time difference in peak $\left(\tau=T_{p w p}-T_{M R(a / o)}\right)$, peak intensity ratio $\left(H_{r}=H_{p w p} / H_{M R(a / o)}\right)$, and integration ratio $\left(S_{r}=\Delta S_{p w p} / \Delta S_{M R(a / o)}\right)$.

\subsubsection{Time difference between $M R_{(a / o)}$ and pore- water pressure peaks for each period}

The time-lag between $M R_{(a / o)}$ and pore-water pressure peaks for pre-snow, snow, and post-snow periods was determined respectively (Figure 10). During the pre-snow periods, time-lag values of 0 to 30 minutes were most frequent, but the values varied greatly with a mean of approximately 150 minutes. Early snow cover periods showed similar tendencies although there were few samples. On the other hand, late snow cover periods showed mean values of 160 minutes, which are similar to those of the pre-snow cover periods, but most frequent time-lag values were 120 to 180 minutes with a certain distribution curve.

Usually, the area along the Sea of Japan is sunny during snow-melting periods, and snow is rapidly melted by short-wave radiation. Since air temperature is closely related with short-wave radiation, short-wave radiation and sensible heat flux melt the snow at the surface of the snow cover every day. Meltwater from the top of snow flows through the snow layer, most or all of which reaches the ground surface. This snowmelting pattern likely regulates the distribution of pore-water pressure. During snow-melting periods, short-wave radiation is maximum at $12: 00$ to $13: 00$ in this district, and therefore the intensity of snow-melt water is maximum at these hours. Meltwater flows down the snow layer in 1 to 2 hours, depending on the thickness of the cover, and runs off to the ground surface. Therefore, the time-lags between $M R_{(a / o)}$ and pore-water pressure peaks suggest that pore-water pressure peaks should appear at 15:00 to $19: 00$.

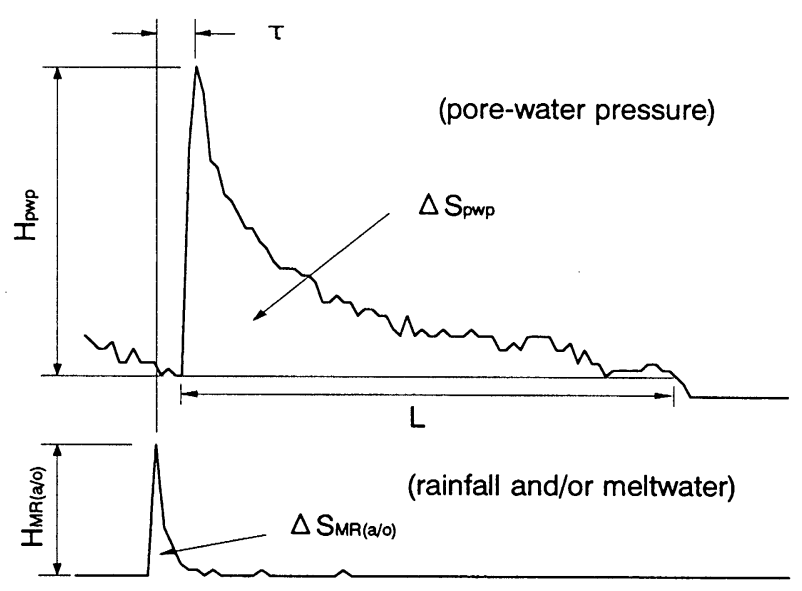

Fig. 9 Pore-water pressure response against rainfall and/or meltwater. 
During post-snow cover periods, the time-lags were shorter than those for late snow cover periods and were usually 30 to 60 minutes. This may be attributable to landslides after the disappearance of snow or to changes of hydrologic coefficients of landslide mass during snow cover periods.

\subsubsection{Comparison of peak $M R_{(\alpha / 0)}$ intensities and} peak pore-water pressure intensities for each period

The peak $M R_{(a / o)}$ intensity and the corresponding peak pore-water pressure intensity were compared (Figure 11). Pre-snow cover periods showed greatly fluctuating intensity ratios, and the ratios fluctuated less during early snow cover periods. During late snow
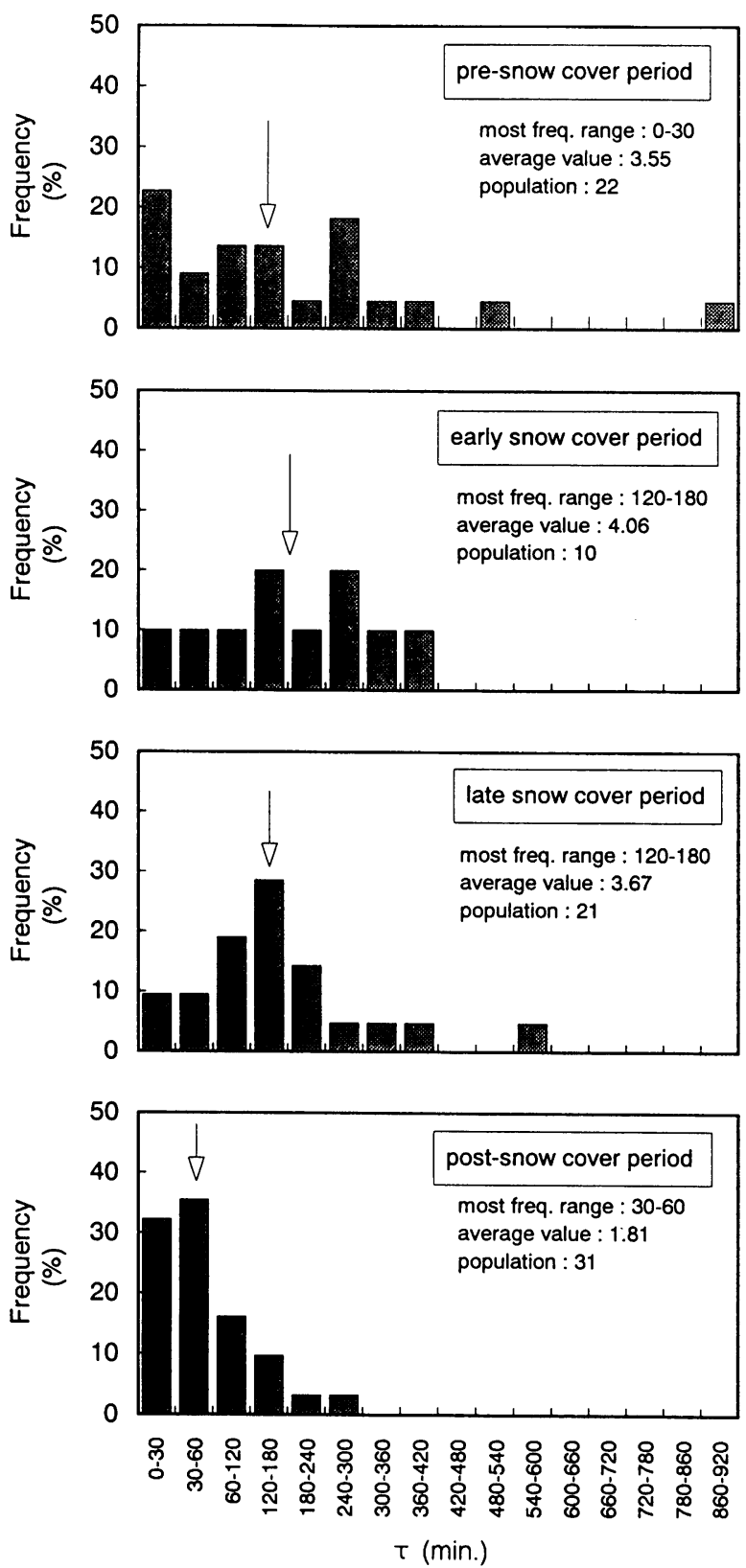

Fig. 10 Time-lag in different periods. cover periods, the peak $M R_{(a / 0)}$ and pore-water pressure values showed a linear relationship while the ratio of peak pore-water intensity to peak $M R_{(a / o)}$ intensity dropped to one third of the ratio compared with those of pre-snow cover periods.

The ratio started to increase when snow cover had disappeared and then showed tendencies similar to those before snow cover periods. Investigations revealed a large difference in peak pore-water pressure intensities against peak $M R_{(a / o)}$ intensities between snow cover periods and no-snow cover periods. Late snow cover periods were especially distinct from other periods, showing smaller diffusion and much lower response ratios.
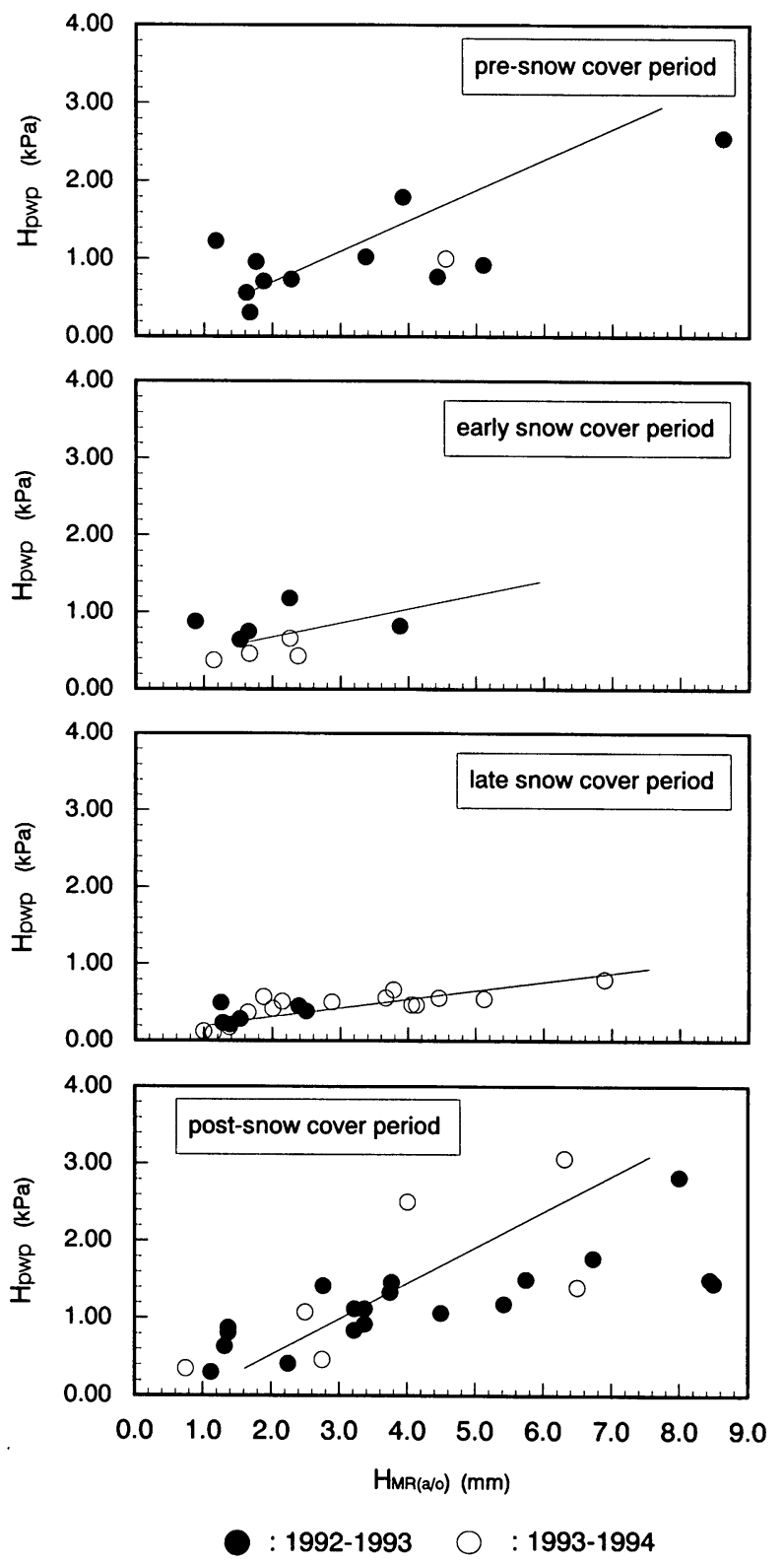

Fig. 11 Relation between $H_{M R(a / o)}$ and $H_{p w p}$. 


\subsubsection{Response ratio between $M R_{(a / o)}$ and pore- water pressure of integrated values for each period}

Next, the relationships between integrated $M R_{(a / 0)}$ values $\left(\triangle S_{M R(a / 0)}\right)$ and integrated pore-water pressure values $\left(\Delta S_{p w p}\right)$ for each period were compared (Figure 12). The response characteristics fluctuated greatly before snow started to accumulate, but the response ratio decreased as snow covered the ground. The response ratios of late snow cover periods were much lower and more correlated $\left(r^{2}=0.92\right)$ than those before snow started to accumulate. At late snow cover periods, $30-60 \mathrm{~mm} /$ day of water was supplied from melting snow, but the response of pore-water pressure was
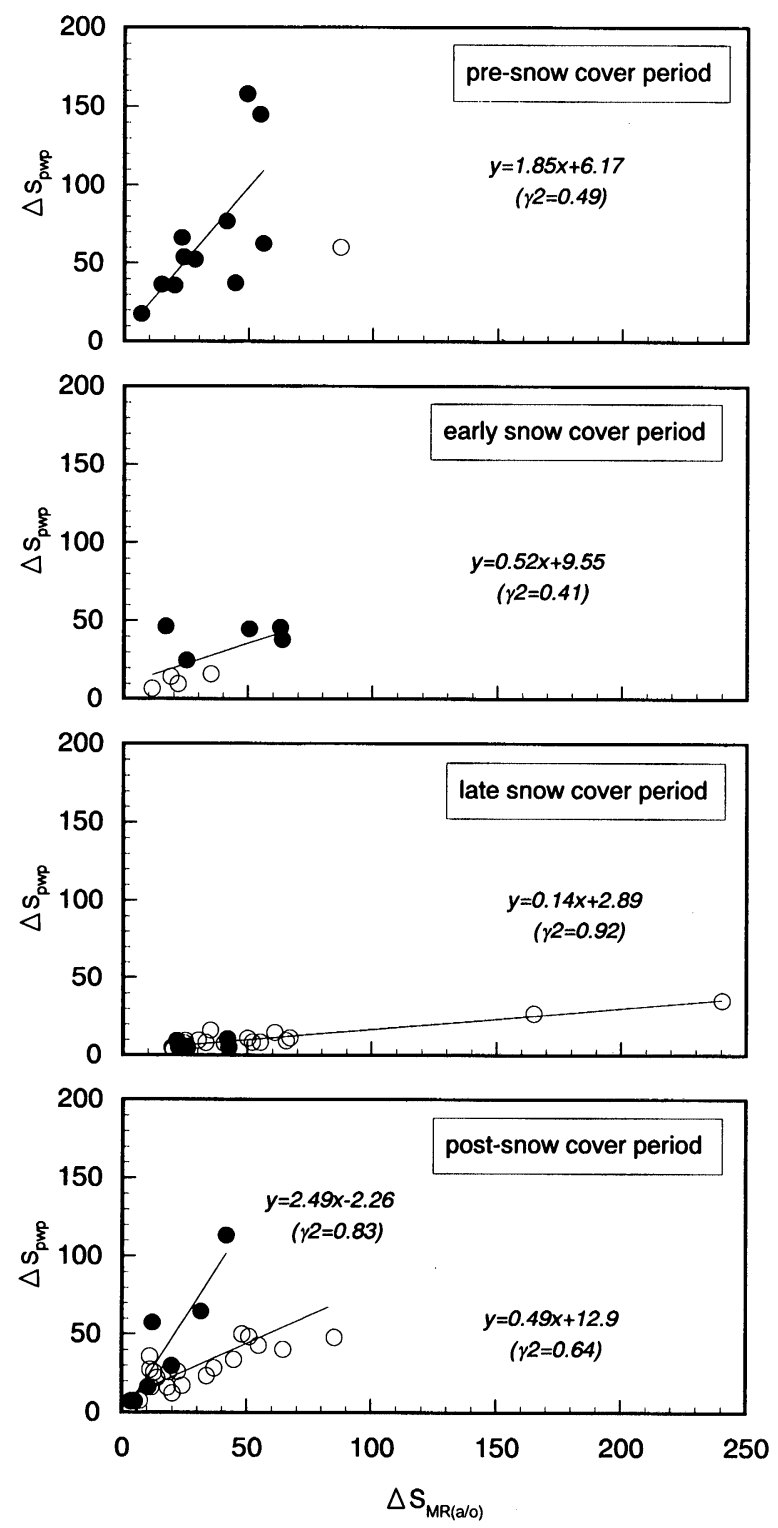

- : 1992-1993 $\bigcirc: 1993-1994$

Fig. 12 Relation between $\Delta S_{M R(a / 0)}$ and $\Delta S_{p w p}$ in different seasons. low. On April 12, 1994, strong wind and high temperature melted snow pack equivalent to approximately $240 \mathrm{~mm}$ of water, which raised pore-water pressure by only $0.6 \mathrm{kPa}$ (Figure 13). One possible cause may be have been saturation of the landslide mass by prior $M R_{(a / o)}$ events, thus inhibiting changes by a new $M R_{(a / o)}$ event. Since fiducial values rose, it is more likely that consolidation by snow load may have affected the void ratio.

The response ratios during post-snow periods much differed by winter year. The amplification ratios were higher in $1993_{\mathrm{wy}}$ than in $1994_{\mathrm{wy}}$. This difference may be attributable to the difference in landslide movement before the snow cover periods. On the other hand, the amplification ratios of late snow cover periods were similar in both winter years.

\subsubsection{Difference in pore-water pressure fluctuation} between periods

Even during a single snow cover period, the early snow cover period and late snow cover period showed different response characteristics of pore-water pressure even when the peak values and total amounts of $M R_{(a / 0)}$ were similar (Figure 14). The upper figure shows the response of pore-water pressure against similar $M R_{(a / 0)}$ values for the $1993_{\mathrm{wy}}$ snow cover period. Pore-water pressure was sensitive at the beginning of the snow cover period, January $\left(S_{r}=0.88\right)$, but showed a response value of half in peak height $\left(S_{r}=0.21\right)$ at the late snow cover period. The lower figure shows the data for $1994_{\mathrm{wy}}$. Although the difference was less notable than for $1993_{\mathrm{wy}}$, the response was lower during the late snow cover period $\left(S_{r}=0.24\right)$ than the value for the early snow cover period $\left(S_{r}=0.63\right)$.

The response at the beginning of the snow cover period differed also by winter years. The $S_{r}$ value for $1993_{\mathrm{wy}}$ was 0.88 and that for $1994_{\mathrm{wy}}$ was only 0.63 , ap-

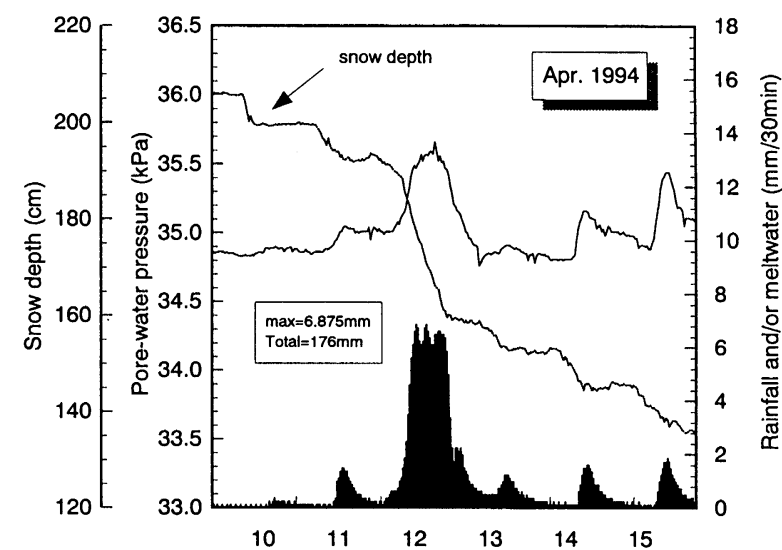

Fig. 13 Observed pore-water fluctuations during a big event in mid April, 1994. 
proximately $70 \%$ of the former year. The snow depth and water equivalent of snow at these times were 122 $\mathrm{cm}$ and $456 \mathrm{~mm}$ for $1993_{\mathrm{wy}}$ and $105 \mathrm{~cm}$ and $465 \mathrm{~mm}$ for 1994 $4_{\text {wy }}$ and did not vary much. Despite such similar conditions, the response of pore-water pressure at the beginning of the $1993_{w y}$ snow cover period was sensitive. A difference in landslide movement is likely the cause of the sensitivity. The total landslide movement at BV9101 from September to January in $1994_{\text {wy }}$ was $1,100 \mathrm{~mm}$, while the total movement for the same period in $1993_{\mathrm{wy}}$ was $1,600 \mathrm{~mm}, 30 \%$ larger. It seems that such a great movement of the mass prior to the snow cover period of $1993_{\mathrm{wy}}$ led to a sensitive response of pore-water pressure against $M R_{(a / o)}$.

For late snow cover periods, the responses of porewater pressure were similar. In $1993_{\mathrm{wy}}$, a rise of 0.43 $\mathrm{kPa}$ was shown against $41 \mathrm{~mm} M R_{(a / o)}\left(S_{r}=0.21\right)$, and a rise of $0.42 \mathrm{kPa}$ was shown against $33.3 \mathrm{~mm} M R_{(a / 0)}\left(S_{r}\right.$ $=0.24)$. However, the snow conditions differed greatly: the snow depth and the water equivalent of snow cover were $204 \mathrm{~cm}$ and $952 \mathrm{~mm}$ in $1993_{\mathrm{wy}}$, and $93 \mathrm{~cm}$ and $353 \mathrm{~mm}$ in $1994_{\text {wy. }}$.

In $1993_{w y}$, the fiducial pore-water pressure values were $1.1 \mathrm{kPa}$ higher at the late snow cover period than at the early snow cover period. The difference was 1.4 $\mathrm{kPa}$ in $1994_{\text {wy. }}$. Since the maximum water equivalent of snow was $1,328 \mathrm{~mm}$ in $1993_{\mathrm{wy}}$ and $1,333 \mathrm{~mm}$ in $1994_{\mathrm{wy}}$, snow loads of $13.0 \mathrm{kN} / \mathrm{m}^{2}$ and $13.1 \mathrm{kN} / \mathrm{m}^{2}$ should have
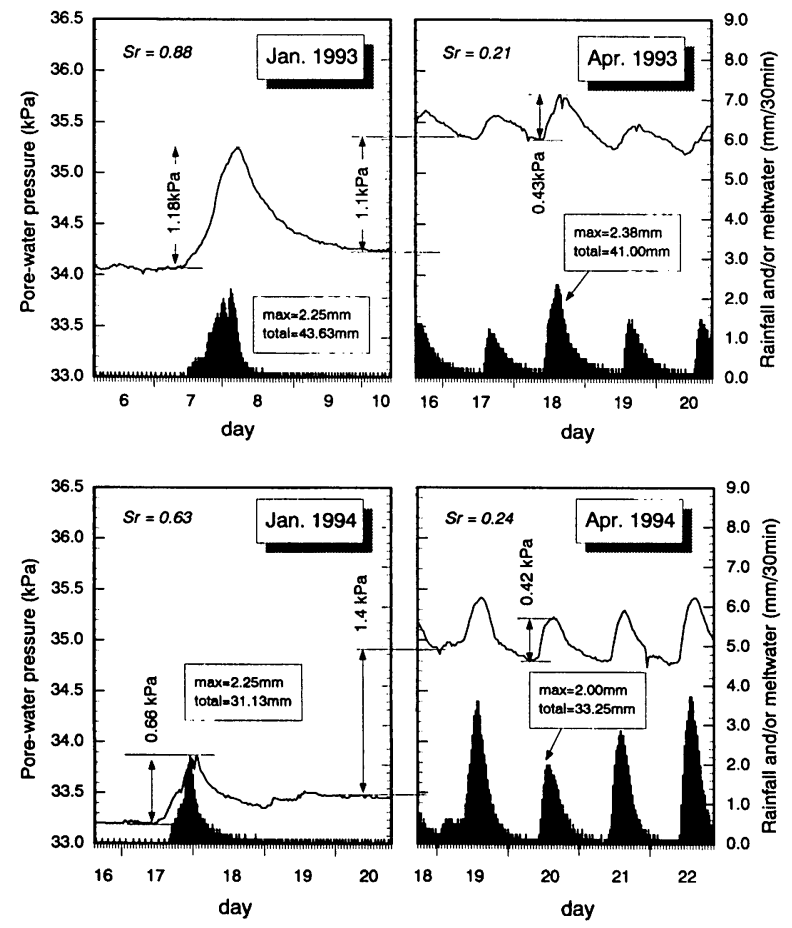

Fig. 14 Fluctuations of pore-water pressure under snow pack in 1993 and 1994. acted on the landslide mass, respectively, although snow cover was unevenly distributed. The landslide moving mass, which had slipped in the past, was likely overconsolidated clay. Snow load on the mass may have caused elastic consolidation behavior and may have increased fiducial pore-water pressure values.

\subsubsection{Response of pore-water pressure after disap- pearance of snow cover}

The fiducial pore-water pressure values started to decline at snow cover periods and continued gradually declining for approximately 700 to 800 hours after snow had disappeared. The responses of pore-water pressure against $M R_{(a / o)}$ (rainfall) during these periods were low immediately after the disappearance of snow but gradually increased thereafter. During late snow cover periods, the response ratios of pore-water pressure against $M R_{(a / o)}$ were 0.1 to 0.2 on average. Heavy rainfall immediately after the disappearance of snow caused no notable response in pore-water pressure. A peak intensity of $5.4 \mathrm{~mm} / \mathrm{h}$ on May 13 to 14,1993 , which marked continuous rainfall of $84.9 \mathrm{~mm}$, caused only a dull response of $0.85 \mathrm{kPa}$ rise in pore-water pressure $\left(S_{r}=0.56\right)$. The response against rainfall gradually became sensitive, and was restored to the level before snow started to accumulate 500 to 600 hours after snow had disappeared (Figure 15).

\section{Conclusion}

From the results of continuous observation of the
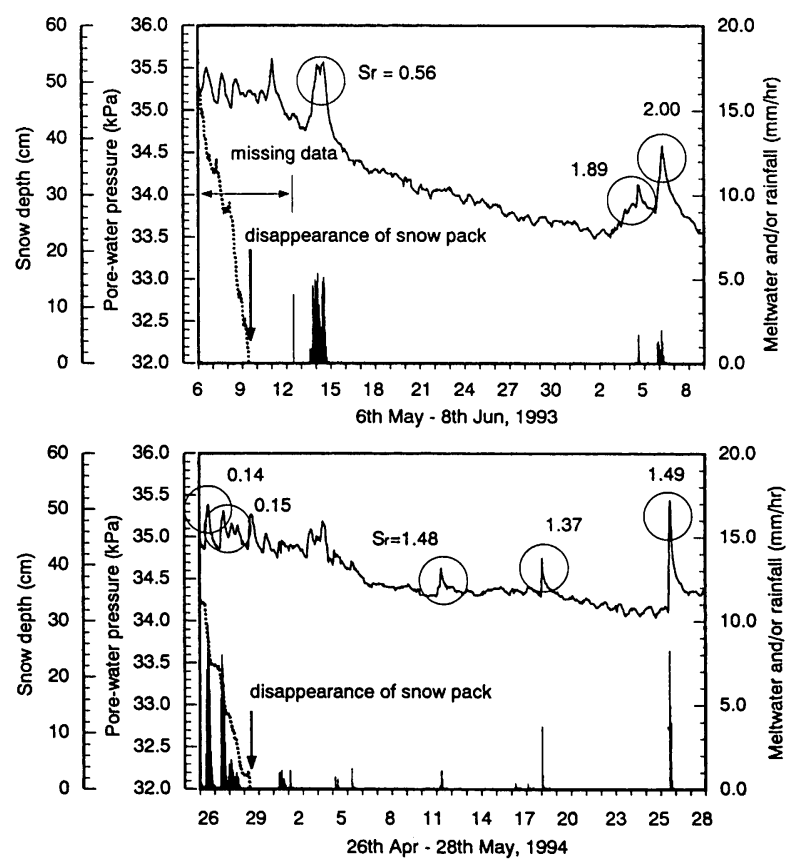

Fig. 15 Pore-water pressure fluctuations consequent to disappearance of snow cover. 
pore-water pressure for two winter years in a landslide with shallow slip surface, the following findings were obtained:

1) Continuous observation showed a gradual rise in pore-water pressure in both $1993_{\mathrm{wy}}$ and $1994_{\mathrm{wy}}$ snow cover periods. Since the change in pore-water pressure was affected more by water equivalent of snow than by snow depth, snow load has likely consolidated the landslide mass and increased the pore-water pressure.

2) The time-lags between the peaks of $M R_{(a / o)}$ and pore-water pressure for pre-snow, snow, and post-snow cover periods were compared. For pre-snow cover periods, the time-lag values varied much, while those for late snow cover periods showed clear distribution curves that peaked at about 160 minutes. During postsnow cover periods, the time-lags were shorter than those for snow cover periods, and pore-water pressure peaks appeared 30 to 60 minutes behind rainfall peaks. 3) After the comparison of the peak $M R_{(a / o)}$ intensities and the corresponding peak pore-water pressure intensities, the relationship was not stable before snow cover periods. However, late snow cover periods showed a close correlation and low response of peak pore-water pressure intensity against peak $M R_{(a / o)}$ intensity.

4) The relationship between the response ratio of porewater pressure against the $M R_{(a / o)}$ value integrated for one event was investigated. Like other results, presnow periods showed fluctuating results. The relationships were less dispersed as snow accumulated, and there was a close correlation during late snow cover periods. The response ratio itself gradually dropped during snow cover periods, and the response ratio for late snow cover periods was one tenth of the pre-snow cover values. After snow had melted, the response ratio was gradually restored.

5) Even during one snow cover period, there were differences in fiducial pore-water pressure value and in the response ratio of pore-water pressure against $M R_{(a / o)}$ between the early snow cover periods and late snow cover periods. The former difference is likely attributable to snow load, and the latter to the history of landslide movement before the snow cover period.

6) The drop in pore-water pressure that started as snow began to melt continued for approximately 700 to 800 hours after snow had disappeared. The response ratio of pore-water pressure against $M R_{(a / o)}$ was low immediately after snow had disappeared, gradually rose thereafter, and was restored to the presnow level in 500 to 600 hours.
Continuous observation of pore-water pressure revealed that pore-water pressure characteristics in snow cover periods are different from those in other periods. These results suggest that the behavior of pore-water pressure at a landslide which has a shallow slip surface is strongly affected by snow cover. Since not only pore-water pressure but also landslide movement seems to be affected by snow cover, precise analyses of landslide movement will be conducted in a future study.

\section{References}

Angeli, M.-G., Gasparetto, P., Silano, S., Tonnetti, G. (1988) : An automatic recording system to detect critical stability conditions in slopes, Proc. of the 5th ISL, Vol.1, Lausanne, 375-378.

Angeli, M.-G., Pononi, F., Gasparetto, P. (1996) : Long-term monitoring and remedial measures in a coastal landslide (Central Italy), Proc. of the 7th ISL, Vol.2, Trondheim, 1497-1502.

Higaki, D., Maruyama, K., Yoshida, K., Yoshimatsu, H. (1991) Pore-water pressure fluctuations in some landslide areas, Jour. of Japan Landslide Soc., 28(3), 9-16. (in Japanese with English abstract)

Ikeda, R., Nakao, K., Sakura Y. (1975): Intermittent landslide caused by remarkable local ground-water flow, Jour. of Japan Landslide Soc., 12(3), 8-16.

Kenney, T. C., Lau, K. C. (1984): Temporal changes of groundwater pressure in a natural slope of nonfissured clay, Can Geotech. Jour., 20, 138-146.

Kondoh, K., Yoshimatsu. H., Yoshida, K. (1992): Characters of groundwater fluctuation in the fractured zone type landslide Jour. of Japan Landslide Soc., 29(2), 39-45. (in Japanese with English abstract)

Larsen, Y. O., Grande, L., Matsuura, S., Asano, S., Okamoto, T., Park, S.G. (1999): Slide activity in quick clay related to pore water pressure and weather parameters, Proc. of the 9th ICFL, 81-88.

Maruyama, K. (1993): Change type of pore-water pressure in landslide area, Jour. of Japan Landslide Soc., 30(1), 27-35. (in Japanese with English abstract)

Maruyama, K. (1994) : Fluctuation of pore-water pressure in the Kuchisakamoto Landslide Area, Jour. of Japan Landslide Soc. 31(2), 32-40. (in Japanese with English abstract)

Matsuura, S., Asano, S., Okamoto, T., Park, S. G. (1998) : Observations of pore-water pressure and landslide movement in Tertiary soft rocks, Proc. of 2nd. Int. Symp. on HSSR, Vol.2, Rotterdam, 1125-1128.

Nakamura H., Kondoh, M., Shiraishi K. (1970): Measurement of underground water level and pore water pressure at a landslide with cohesive soil as the principal constituent, Jour. of Japan Landslide Soc., 7(1), 1-7 (in Japanese)

Ogawa, S., Ikeda, T., Kamei. T., Wada T. (1987) : Field investigations on seasonal variations of the groundwater level and pore water pressure in landslide areas., Soil and Foundations, 27(1), $50-60$.

Okamoto, T., Asano, S., Matsuura, S., Larsen, Y. (1999): Monitoring of landslide movement in quick clay deposit area, Jour. of Japan Landslide Soc., 36(2), 39-47. (in Japanese with English abstract)

Sangrey D. A., Harrop-Willams K. O., Klaiber J. A. (1984): Predicting ground-water response to precipitation, Jour. of Geotech. Engin., 7, 957-975.

（原稿受理日 平成12年 2 月 3 日） 
繰り返し一面せん断試験によるカオリン粘土のせん断面の構造と形成過程

「地すべり」Vol. 37, No. 2 (通巻142号）pp. 1 9, 2000年（平成12年）9月

大河原正文, 三田地利之, 棚田 真, 藤村正二, 米田哲朗

圧密定圧, 圧密定体積およびプレカット供試体による圧密定圧の 3 つの試験条件の下で繰り返し一面せん断 試験を行い，試験後のせん断面の層構造と粒子の配向性を定量的手法により評価した。

その結果, 主変位せん断面の配向度は, 累積水平変位 $48 \mathrm{~mm}$ のとき, 定圧試験（ $M=97.3 \%)$ とプレカット 定圧試験 $(M=99.2 \%)$ では，ほぼ100\%で，かつペッドの最頻度配向方向が $\alpha$ mode=0 ペッドはせん断方向に完全配向していることが明らかになった。このように定圧試験とプレカット定圧試験に おいて, 残留状態の配向条件を満たしている（主変位せん断面の完全配向）ことから，これらの試験条件に基 づいて実施された繰り返し一面せん断試験結果から残留強度として妥当な值を得ることが出来る。

\section{Fluctuation of Pore-water Pressure in a Landslide of Heavy Snow districts}

「地すべり」Vol. 37, No. 2 (通巻142号) pp. 10 19, 2000年（平成12年）9月

SUmio MATSUURA

多雪地带に位置する第三紀層の浅層のすべり面をもつ地すべり地で, 積雪深や積雪水量などの積雪環境に関 する観測を行うとともに，降雨もしくは融雪水など地表面に供給される水量 (Meltwater and/or Rainfall： $\left.M R_{(a / 0)}\right)$ と地すべり移動体内部の間隙水圧の自動観測を行った。観測の結果, 積雪期間中は間隙水圧が緩や かに上昇するのに対し，各 $M R_{(a / 0)}$ に対する間隙水圧の応答は低くなるなど，他のシーズンとは全く異なる変 動を示すことが明らかになった。これらは, 積雪が浅層の地すべりに対して荷重として働き, 地すべり移動体 内部の水文定数が変化したことを示すものと考えられる。

\section{“七面山大崩れ”}

一崩壊の履歴とその拡大に関する研究一

「地すべり」Vol. 37, No. 2 (通巻142号) pp. 20 29, 2000年（平成12年）9月

永井 修, 中村浩之

山梨県南西部に位置する “七面山大崩れ”は安政の東海地震（1854）で大崩壊したという説が一般的であっ たが，今回七面山と関連の深い日蓮宗久遠寺の古文書や文献を精查の結果，“七面山大崩れ”は1600年代には 既に崩壊してきたことが明らかとなった。また“七面山大崩れ”は過去に発生した幾度かの地震や毎年の削剥 を経て現在の地形に至ったものであり, 一度の地震をひきがねとした大規模崩壊ではない。特に毎年の削剥量 は冬季における凍結融解によるものが大半であり, 七面山における特異な地形, 地質と南向き斜面の微気候が 崩壊の拡大に影響している。

\section{高純度粘土鉱物のリングせん断特性}

一すべり面粘土との対比一

「地すべり」Vol. 37, No. 2 (通巻142号) pp. 30 39, 2000年（平成12年）9月

\section{山崎孝成, 眞弓孝之, 由田恵美}

実際のすべり面粘土と対比するために，高純度粘土鉱物のリングせん断試験を実施し，以下の知見を得た。 (1)残留強度はIllite $\phi_{r}{ }^{\prime}=14.5^{\circ}>$ chlorite $\phi_{r}{ }^{\prime}=11.0^{\circ}>$ sericite $\phi_{r}{ }^{\prime}=9.7^{\circ}>$ montmorilonite $\phi_{r}{ }^{\prime}=3.8^{\circ}$ 。(2)モンモリ ロナイトは膨圧と強度回復に相関がある。(3)残留強度は荷重変化にも関わらず，すべての試料で安定した値を 示す。(4)クロライトとセリサイトの混合試料はクロライトの含有率 $49 \%$ を境に遷移点があり，これを越えると クロライトの残留せん断強度を示す。モンモリロナイトとイライトの混合試料はモンモリロナイト含有率が $30 \%$ を越えるとほぼモンモリロナイトの残留せん断強度 $\phi_{r}{ }^{\prime}=4.0$ の值を示す。(5すべり面粘土との対比では, クロライト・セリサイト混合試料が緑色岩類を起源とするすべり面粘土とほぼ同じ值を示し, 変成岩類起源の すべり面粘土残留強度の下限值を与える。モンモリロナイト・イライト混合試料は第三系の泥岩を起源とする すべり面粘土に良く対応し，モンモリロナイトの含有率に大きく影響を受けている。 